\title{
Driving force analysis of East European students to study tourism and hospitality in the UK
}

\author{
Dr Roya Rahimi \\ Lecturer in Tourism, Hospitality and Event Management \\ Department of Marketing, Innovation, Leisure and Enterprise \\ University of Wolverhampton, United Kingdom \\ Tel: 01902323117 \\ Email: roya.rahimi@wlv.ac.uk \\ $\&$ \\ Dr Y1lmaz Akgündüz \\ Associate Professor in Tourism Management \\ Dokuz Eylul University, Izmir, Turkey \\ yilmazakgunduz@hotmail.com
}

\begin{abstract}
Using a push-pull model this current study tries to investigate the relative importance of the UK as a location focus for East European students to undertake a Higher National Diploma (HND) in Tourism and Hospitality. The research conducted is based upon a mixed method approach through two sequential phases, a focus group and a questionnaire. The results revealed that the opportunity to improve language skills, financial support from the UK government and job opportunities are the important factors for selecting the UK. The results further showed that the nature of the course, Precourse expectations and external impacts, such as benefits for EU citizens (student loans) are key factors for choosing to study Tourism and Hospitality.
\end{abstract}

Keywords: Student motivation; Higher National Diploma (HND); East European students; tourism education; hospitality education

\section{Introduction}

In the last decade, along with other western countries, the UK has experienced a significant increase in the number of international students for its higher education qualifications (UK Council for International Affairs, 2016). According to the Higher Education Statistics Agency (HESA) (2015) in 2014/15, UK domiciled students accounted for $81 \%$ of all enrolments at UK Higher Education (HE) providers (the same as in 2013/14), 5\% were other European Union (EU) domiciled (the same as in 2013/14) and the remaining 14\% came from countries outside the EU (13\% in 2013/14). The Higher National Diploma (HND) is a vocationally focused higher education qualification offered in the UK by Higher and Further Education (FE) colleges. HND qualifications are equivalent to the second year of a three-year university degree course and can be used to gain entry to a university in England and Wales (UCAS, 2016). The qualification is awarded by different awarding bodies, such as BTEC (Pearson Edexcel Vocational programs), The Confederation of Tourism and Hospitality (CTH Advanced diploma) and the Scottish Qualifications Authority (SQA). 
Since 1999 there has been a worldwide campaign to promote British education and make the UK first for quality and choice for international students. Currently, the UK is the second leading exporter of education, behind the USA, and British Universities have a growing popularity among talented, high-paying students from the rest of the world (Binsardi \& Ekwulugo, 2003). The UK is also one of the popular destinations for EU students, not just because of the quality of the education, but also the eligibility of EU students for the same low-interest government loans as those taken out by the British students. Enrolling for HND qualifications has doubled in the UK, from 13,000 to 30,000 in 12 months since 2013, and since 2012 UK Colleges have been hit with a large number of applications from East European students ${ }^{1}$. In 2013 more than 5,000 East European students enrolled on vocational courses in England, accounting for a staggering one in six of all applicants. According to the UK Council for International Student Affairs (UKCISA, 2016) and the Independent (2013), Romania and Bulgaria are among the top ten EU sending countries when it comes to education in the UK, with 4,625 and 4,615 students being entitled to up to $£ 10,000$ in UK grants and loans for their study.

Support from the loan company is only available to EU citizens resident in the UK for a minimum of three years. Those already living in the UK are also entitled to a maximum $£ 3,400$ maintenance loan for living costs. From 2012/13 The Student Loans Company lent almost $£ 4.5$ billion in tuition fee loans (HESA, 2013). Tourism and hospitality, under the broader subject of business and management, is amongst the most popular HND courses in the UK colleges. A number of studies in various disciplines have reported on the reasons why students choose a particular country to complete their studies and then investigated their experiences (Altbach \& Knight, 2006; James, McInnis, \& Devlin, 2002; O'Brien, Webb, Page, \& Proctor, 2007; Varghese, 2008; Ward \& Masgoret, 2004). Such research studies can be also found in the hospitality and tourism field (Bushell, Prosser, Faulkner, \& Jafari, 2001; Huyton, 1997; Kim, Guo, Wang, \& Agrusa, 2007; Lee, Kim, \& Lo, 2008; O'Mahony, McWilliams, \& Whitelaw, 2001; Purcell \& Quinn, 1996; Rahimi, Williams, Gursoy, Yolal, \& Lee, 2015; Zhao, 1991).

Considering the popular position of the UK with East European students and the significant increase in the volume of their movements in the recent years, the current study seeks to investigate 1) the driving forces of East European students to select the UK as an educational destination, and 2) their motivations to study HND in Tourism and Hospitality management. The author's will try to investigate these factors using push-pull models (Altbach, 1998; Mazzarol \& Soutar, 2002; McMahon, 1992; Rahimi, Nadda, \& Muldiwa, 2016) at two different stages, 1) motives for selecting the UK as an educational Hub and, 2) motives for the selection of a HND in Tourism and Hospitality. The findings of this study will help FE and HE providers to understand their students' motives better and ensure that the best possible learning environments are provided. The study will also address a number of key questions regarding the current situation and the future of EU students and FE providers, as well as the underpinning of policy regarding EU student recruitment. Finally, the study provides some marketing implications for the recruiting agencies and advises for tourism and hospitality industry.

\footnotetext{
${ }^{1}$ Eastern Europe includes the countries of Russia, the Czech Republic, Poland, Hungary, Romania, Moldova, Croatia, Lithuania, Latvia, Estonia, Slovenia, Slovakia, Bulgaria, Ukraine, Belarus, Serbia, Montenegro, Bosnia and Herzegovina, Albania, Kosovo and Macedonia.
} 


\section{Literature review}

Pintrich (2003), in his study, mentioned that the term motivation is derived from the Latin verb movere, which means to move, hence motivational theories are concerned with the energization and direction of behaviour. This means that motivational theories attempt to answer questions about what gets individuals moving (energization) and towards what activities or tasks (Pintrich and Schunk, 2002). There are different models that try to investigate this motivation and cover all aspects related to it. Dörnyei (1998), based on his comprehensive review of the main theoretical and research literature into motivation, mentioned that no available theory has yet managed to represent it in its total complexity. Pintricht and Schunk (2002) in their study, highlight a shift in emphasis from more traditional views of motivation, as a fairly static mental or emotional state reflecting inner forces or behavioural contingencies, to a more process-oriented approach in which individuals' thoughts and beliefs play the predominant part.

Williams, Burden and Lanvers (2002) in their study, mentioned researchers in the motivation studies area face the dilemma of attempting to draw together aspects of these different, and sometimes even contradictory approaches, or of selecting one theoretical perspective (e.g. self-efficacy theory), and then focusing their research efforts on this. Looking at the educational context, and going through different motivational models (Weinberger \& McClelland, 1990) for international student movement, (Altbach, 1970; King \& Ruiz-Gelices, 2003) we found that the majority of students who leave their countries for educational purposes are influenced by push-pull factors (Altbach, 1998, Bodycott, 2009; Li \& Bray, 2007; Mazzarol \& Soutar, 2002;). Push factors are those that operate within a country and initiate a student's decision to undertake study abroad. These include economic, social, and political forces within the source country. Pull factors are those that make another country attractive to students (Mazzarol \& Soutar, 2002). Altbach (1998) pointed out that some students were pushed by unfavourable conditions in their home countries, while others were pulled by scholarships and other opportunities in host countries. Considering the main objectives of this study, our work has been greatly influenced by push-pull models (Altbach, 1998; Mazzarol \& Soutar, 2002; McMahon, 1992; Rahimi et al., 2016) which directed the focus group part of the study and consequently the design of the questionnaire.

Nowadays international students have more study options than ever before. Understanding why students participate in formal higher education has been a key focus of educational researchers (Altbach \& Knight, 2006; James et al., 2002; O'Brien, Webb, Page, \& Proctor, 2007; Varghese, 2008; Ward \& Masgoret, 2004). Anderson et al. (1998) in their study mentioned that although personal interest in the study area is still a major driver, professional and financial advancement is also a key factor. Suvantola (2004) found self-development and knowledge enhancement as important factors, and further, Kyriacou and Coulthard (2000) and Moogan and Baron (2003) found students motivated by subject interest and enhancement of professional practice. Davey (2005) investigated Chinese postgraduate students studying in the United Kingdom and found that these students were motivated by; the quality of the education, course reputation, opportunity to develop their English language and communication skills, the Western culture, social networking opportunities, personal development and the immigration opportunities after their studies.

Rahimi et al. (2016) found that the majority of South Asian students in the UK are motivated by their friends and relatives; the opportunity to improve their English and enjoy a multi-cultural environment. According to Mazzarol and Soutar (2002), the decision to study abroad is sometimes made by members of the family, and this applies to postgraduate as well as graduate levels. They 
further highlighted in their research that the parental influence is higher among undergraduate students when they are choosing a country or a destination to study. To some extent the decision of the students choosing the destination, can be so influenced by others that the students end up studying in the countries or disciplines that would not necessarily have been their choice if they were able to make their own decision. Mazzarol and Soutar (2002) pointed out that other factors influencing the selection of a country have been a commonality of language, the availability of science or technologybased programmes and the geographic proximity of the home and host countries.

Patterns and motivations of student migration to Western countries are investigated by a variety of studies (Baldwin \& James, 2000, Gomes \& Murphy, 2003; Mazzarol \& Soutar, 2001, Mazzarol \& Soutar, 2002, Moogan, Baron, \& Harris, 1999; Rahimi et al., 2016). The findings of these studies suggest that the process of decision-making and motivations for overseas students differ from EU students. For example, Maringe and Carter (2007), found that Taiwanese students choose to study abroad because they consider the international acceptability and recognition of UK higher education as a tremendous benefit for their long-term investment. On the other hand, EU students choose to come into UK higher education mainly because it provides them with an opportunity to learn the English language and British cultural traditions (Davey, 2005). Moogan and Baron (2003) in their research, found that the characteristics of the student influenced their decision, and that the prospectus is the most important source of information. Course content is more important to females, whereas reputation is more important to males.

\section{Tourism and hospitality education}

Tourism emerged as a field of academic research and education during the Interwar years when it was necessary to rebuild cities and infrastructure decimated by conflict. Regimes from across the political spectrum utilised tourism for various ideological and economic ends (Kozak \& Kozak, 2017). Tourism was introduced as a subject by European Universities in the 1930s (Faulkner, 2003; Ruhanen \& McLennan, 2010) and the economic importance of the industry has created ever increasing demand for skilled and qualified human resources in the labour market, thus convincing both government and education providers to offer it as a part of wider programmes at various levels. The supply of tourism courses has been met by an increasing student demand, and since then there has been a sustained level of applications for tourism related courses (Dale \& Robinson, 2001). Different numbers of studies have investigated the motivation of students to study Tourism and Hospitality (Cole, Cole, \& Ferguson, 2006; Lee et al., 2008; O'Mahony et al., 2001; O’Mahony, Whitelaw, \& Whitelaw, 2008; Stuart-Hoyle, 2003; Wickens, Forbes, \& Tribe, 2006).

According to Bushell et al. (2001), students join Tourism and Hospitality programmes because the industry provides benefits through its contribution to cultural enrichment and economic growth, and provide challenging and exciting career opportunities for people with a variety of talents and interests. Different research has indicated other factors have comprised an increase in employment and travel opportunities, career advancement and wage improvements (Hannam, Mitsche, Stone, \& Mordue, 2004). Ross (1992) suggests that secondary school students in Australia had a high level of interest in management positions in the tourism and hospitality industry and that they were prepared to undertake vocational preparation to achieve such positions. The study further suggested that the tourism and hospitality industry is now regarded as holding considerable promise for future employment and careers prospects in many western countries, hence attracts more students to invest their future in it. Rahimi et al. (2016) in their study found that South Asian students select the UK to study tourism and hospitality courses because they have friends and family in the UK. 
Additionally, they can improve their English, the UK visa process is easier compared to other countries and they have the opportunity to work for 20 hours per week. The study further found that a tourism and hospitality degree can give them better job opportunities in the future.

The UK is also one of the popular destinations for EU students, not just because of the quality of the education, but also because the places are subsidised by the taxpayer and EU students are eligible for the same low-interest government loans as those taken out by the British students. Since 2004, there has been a rise in migration to the UK from eight EU countries (the Czech Republic, Estonia, Hungary, Latvia, Lithuania, Poland, Slovakia, and Slovenia) and subsequently from Romania and Bulgaria in 2007 (Blanchflower \& Shadforth, 2009). After the new member states joined, the demand from EU students increased by 33\%. Applicants from Lithuania and Latvia have more than doubled, while those from Romania have increased by more than $70 \%$. Figures also showed that more than 5,000 places at Russell Group universities were taken up by EU students last year, an increase of one third in just three years (Telegraph, 2010). Considering the popular position of the UK with East European students and the significant increase in the volume of their movements in the recent years, this current study tries to investigate the driving forces of East European students in selecting the UK as a destination, and their preferred concentration of study for a HND in Tourism and Hospitality.

\section{Methodology}

Towards achieving the research's objectives, the study is conducted using a mixed method approach through two sequential phases of qualitative and quantitative research. Mixed methods refers to an emergent methodology of research that advances the systematic integration, or "mixing," of quantitative and qualitative data within a single investigation or sustained program of inquiry (Greene, Caracelli \& Graham, 1989; Rahimi et al., 2016). Applying mix methods helped the researchers to find more in-depth information about student's motivations in the phase on during the qualitative research and also the most dominant factors among a larger group during the phase two - quantitative research. This increased the comprehensiveness of the overall findings, expanded the dimensions of the research topic and increased the methodological rigour as findings in both phases could be checked for consistency (Chow, Quine, \& Li, 2010).

\section{Qualitative phase}

Data collection started with a focus group to find in-depth information about student's motivations to select the UK and to study for a HND in tourism and hospitality. In this phase, in order to gain a variety of perspectives, 10 East European students (level 3 to level 5) were selected from a tourism and hospitality course (HND) in one of the leading FE providers in the UK. The HND course is offered by BTEC Edexcel Pearson. For the focus group, a set of push-pull factors, extracted from Altbach (1998), Mazzarol and Soutar (2002), McMahon (1992) and Rahimi et al. (2016) studies, are used as prompts for facilitating the focus group. The focus group was conducted for an hour and students were encouraged to talk about their motivations to select the UK and further the reasons for studying tourism and hospitality. With the permission of all participants, the focus group was recorded, transcribed, and the data was analysed via an inductive approach and content analysis method (Elo \& Kyngäs, 2008; Hsieh \& Shannon, 2005; Ritchie, Spencer, Bryman, \& Burgess, 1994). Under the two main themes of Selecting the UK and Study Tourism and Hospitality, in total, 19 pushpull factors were extracted as the codes, see (Table 1).

\section{Quantitative phase}


In the second phase, using a quantitative approach, the collected codes from the focus group were used to design a questionnaire to investigate the most dominant motivational factors influencing the students' decision-making process. The questionnaire comprised of three sections: a) a set of pushpull factors for selecting the UK, b) a set of push-pull factors to select Tourism and Hospitality, and, c) demographic questions. The questionnaire was based on a 5 point Likert-Scale, with 1 equating to strongly disagree, and 5 to strongly agree. The population of the study consisted of 500 East European students studying for a HND in tourism and hospitality (level 1 to level 3), in one of the leading FE providers in the UK. Firstly, a pilot study was conducted with 5 students, and after a few spelling and grammar changes, the final questionnaire was designed using Survey Monkey. The questionnaire was distributed via a Virtual Learning Environment (VLE) owned by the college. One week later, first reminder e-mails were sent out, after two weeks, second reminders, and after four weeks, final reminders were sent to the students. In total 204 usable responses were collected and data was subjected to reliability, exploratory factor analysis, correlation, and regression analysis.

\section{Results}

\section{Qualitative results}

The results of the focus group revealed a set of motivational factors for selecting the UK and for studying tourism and hospitality.

\section{Stage 1 - Selecting UK}

Regarding the UK as an educational destination, most of the students mentioned that they selected the UK because they have friends and family in the UK; it is close to their home countries, they have the opportunity to improve their English and they can enjoy a multi-cultural environment (they feel welcome). The good reputation of the UK education system was also mentioned as one of the reasons for selecting the UK. One of the students commented;

With the UK qualification I can find a job almost everywhere in the word but if I have a qualification from Romania or Czech no one give a sh.. to it.

They also mentioned that the UK can offer them job opportunities and freedom to work while studying. Almost all of the students mentioned support from the student loan company in the UK as one of the most important factors. One of the students mentioned that;

Getting the financial support for my education was the initial motivation to start my study.

Another student said;

I was a taxi driver and my friend told me that I can earn money while studying so I came to the college and left my job.

\section{Stage 2 - Study tourism and hospitality}

The second part of the focus group tried to identify the main reasons students study tourism and hospitality. Almost all students mentioned that initially they did not have any special motivation and it was financial support from the college that encouraged them to enrol. During this part of the focus group one of the students kept saying "Money, Money, Money,..is the MOTIVATION!". 
Some of the students mentioned that they are currently working in tourism and hospitality or have previous work experience, and they believe studying will facilitate their career progress. One of the students said

I used to work in a hotel as the receptionist in my country and now I am working as a housekeeper but my manager promised to promote me after my first year.

Encouragement and influence from friends and family was mentioned by most of the students. It needs to be mentioned also that encouragement was mainly in the form of the support from the student finance company and the possibility of earning easy money. One of the students said, "I can get commission if I bring my friends".

Another student said that:

I did not know anything about tourism and hospitality and my friend told me you can study and earn money!

Most of the students mentioned that tourism is an easy field (no maths or economics involved). Some of the students mentioned that they have been interested in traveling and geography, hence they thought, as part of the course, they would find opportunities to travel abroad (field and residential trips). One of the students said,

I visited 28 countries and traveling is my hobby so I decided to study tourism.

The majority of the students believed that tourism and hospitality is an enjoyable major and has a pleasant working environment. One of the students said,

I love socializing and tourism and hospitality workplaces give me the opportunity to talk with people.

Most of the students decided to do vocational tourism and hospitality courses because of their practical rather theoretical nature. One of the students said

I used to work for a lady who had a coach and arrange summer field trips for students. I loved it so I thought I go to this course to learn practical skills but the modules are more theoretical than practical.

Finally, the students mentioned that being students in tourism and hospitality means more job opportunities during their studies. Under the two main themes of Selecting the UK and Study Tourism and Hospitality in total, 19 motivational push-pull factors were extracted as the codes from the focus group. These factors were used for the second phase of the research and in designing the questionnaire.

Table 1 -Emerged themes and codes from the qualitative part

\begin{tabular}{cl}
\hline Theme & \multicolumn{1}{c}{ Codes } \\
\hline & UK education has a global reputation. \\
& I can improve my English. \\
I can settle in the UK after study. & UK has a good currency exchange. \\
Selecting UK & UK is a multicultural country. \\
It can be like a platform and I can move to a better country in the
\end{tabular}


future.

It is close to home.

There is not any visa issue.

It is easy to find a job in the UK.

I can get financial support in the UK.

Tourism and Hospitality is an enjoyable major.

Tourism and Hospitality has a pleasant working environment.

There are a lot of job opportunities in this field.

My friends influenced my decision.

Study My family encouraged me to study this field.

Tourism and I did not have any specific interest but because it was financially

Hospitality supported I decided to do it.

I thought classes are more practical rather than theoretical.

Traveling is my hobby and I wanted it as a career.

It is an easy major in comparison to other fields such as business.

\section{Quantitative results}

19 items were extracted from the focus group and used for designing the questionnaire. In total 204 usable responses were collected for the quantitative analysis part of the research. The majority of respondents $(56 \%)$ were female. Almost $58 \%$ of the respondents were more than 40 yrs. old. 58\% of the respondents were Romanian and the rest were from Bulgaria, Latvia, Poland and Lithuania.

\section{Reliability}

A test of internal reliability was taken before analyzing the objectives of the research. This assessment is of high importance in order to ensure that the information has a depth of consistency present amongst the ratings given by the respondents from all of the collected data (Pallant, 2007). The most commonly used quantitative measurement is Cronbach's alpha confidence (Hair, Celsi, Money, \& Samouel, 2015) where values above 0.60 can be considered acceptable to proceed without any further analysis (Pallant, 2007). The overall Cronbach's alpha for selecting the UK part is 0.734 , indicating an acceptable level of internal consistency. The Cronbach's alpha of the factors in this part are varying from 0.586 to 0.611 and demonstrate acceptable internal consistency. The overall Cronbach's alpha for the selecting tourism and hospitality part is 0.689 , which demonstrates an acceptable level of internal consistency. The Cronbach's alphas of the factors in this part are varying from 0.546 to 0.653 , and demonstrate an acceptable level of internal consistency (Rahimi and Gunlu, 2016).

\section{Exploratory Factor Analyses}

In order to identify the potential sub-groups for two stages, two different exploratory factor analyses have been employed. For this purpose, the principal component method of factor analysis was carried out with Eigenvalues greater than one through the varimax rotation and the results obtained through rotated component matrix are presented in Table 2.

\section{Stage 1- Selecting the UK}

The results of exploratory factor analysis of selecting the UK are shown in table 2. The KaiserMeyer-Olkin was 0.775 above the recommended value of 0.60 and Bartlett's test of sphericity was significant (Hair and Lukas, 2014). The diagonals of the anti-image correlation matrix were all over 0.50 , supporting the inclusion of each item in the factor analysis. Finally, the commonalities were all 
above 0.30 further confirming that each item shared some common variance with other items. Factor analysis for selecting the UK showed three independent groups. We labeled these groups as below, which accounted for a total of 54.575 percent of variations on 10 attributes.

- Opportunities and Reputation of UK Education (Pull factors)

- UK Opportunities (Pull factors)

- Benefits of Being an EU Member (Pull factors)

The opprtunities and reputation of the UK Education group consist of three variables, "the UK education has a global reputation", with a factor loading of 0.709", "I can improve my English", with a factor loading of 0.683 " and, "I can settle in the UK after study", with a factor loading of 0.659". The UK Opportunities (Pull factors) group consists of three pull factors, "the UK has a good currency exchange", with a factor loading of 0.732 , "the UK is a multi-culture country", with a factor loading of 0.650 and "It can be a platform and I can move to a better country in the future", with a factor loading of 0.618. The Benefits of Being an EU Member (Pull factors) group consists of four pull factors, "It is close to home", with a factor loading of 0.705 , "There is not any visa issue", with a factor loading of 0.633 , "It is easy to find a job in the UK", with a factor loading of 0.625 , and "I can get financial support in the UK" with a factor loading of 0.432 .

\section{Stage 2 - Selecting tourism and hospitality courses}

The results of exploratory factor analysis for selecting tourism and hospitality courses are shown in table 2. As it shown, Kaiser-Meyer-Olkin was 0.684 , above the recommended value of 0.6, and Bartlett's test of sphericity was significant (Hair \& Lukas, 2014). The diagonals of the anti-image correlation matrix were all over 0.5 , supporting the inclusion of each item in the factor analysis. Finally, the commonalities were all above 0.3 , further conf

irming that each item shared some common variance with other items. Factor analysis for selecting the UK as education hub variables showed three independent groups. We labelled them as below, which accounted for a total of 59.389 percent of variations on 9 attributes.

- Course Nature (Pull factors)

- External Impacts (Push factors)

- Pre-course Expectations (Push and pull factors)

The Course Nature group consists of following variables; "Tourism and Hospitality is an enjoyable major" with a factor loading of 0.811 , "Tourism and Hospitality has a pleasant working environment", with a factor loading of 0.804 and "There are a lot of job opportunities in this field", with a factor loading of 0.527. External Impacts group consists of three push variables of "My friends influenced my decision", with a factor loading of 0.816, "My family encouraged me to study this field", with a factor loading of 0.754 and "I did not have any specific interest but because it was financially supported I decided to do it", with a factor loading of 0.679. Pre-Course Expectations group consist of three pull variables of "I thought classes are more practical rather than theoretical" with a factor loading of 0.760 , "Traveling is my hobby and I wanted it as a career", with a factor loading of 0.732 , and "It is an easy major in comparison to other fields such as business", with a factor loading of 0.560 .

Table 2. Factor analysis of affecting the choice to select UK and tourism and hospitality Factor analysis of selecting UK

Factor Loadings

Mean

Eigen

$\%$ of 


\begin{tabular}{|c|c|c|c|c|c|}
\hline \multirow{2}{*}{\multicolumn{2}{|c|}{ Opportunities and Reputation of UK }} & & \multirow{2}{*}{$\begin{array}{c}\text { Value } \\
3.022\end{array}$} & \multicolumn{2}{|l|}{ Variation } \\
\hline & & 4.11489 & & 19.850 & .601 \\
\hline \multicolumn{6}{|l|}{ Education (Pull) } \\
\hline UK education has a global reputation. & .709 & 4.2353 & & & \\
\hline I can improve my English. & 683 & 4.4216 & & & \\
\hline I can settle in the UK after study. & 659 & 3.7892 & & & \\
\hline UK Opportunities (Pull) & & 3,7353 & 1.306 & 17.642 & .586 \\
\hline UK has a good currency exchange. & .732 & 3.6716 & & & \\
\hline UK is a multicultural country. & .650 & 4.2255 & & & \\
\hline $\begin{array}{l}\text { It can be like a platform and I can move } \\
\text { to a better country in the future. }\end{array}$ & .618 & 3.3088 & & & \\
\hline $\begin{array}{l}\text { Benefits of Being an EU Member } \\
\text { (Pull) }\end{array}$ & & 3.5637 & 1.130 & 17.082 & 611 \\
\hline It is close to home. & .705 & 3.0637 & & & \\
\hline There is not any visa issue. & .633 & 3.5294 & & & \\
\hline It is easy to find a job in the UK. & 625 & 3.7108 & & & \\
\hline I can get financial support in the UK. & .432 & 3.8431 & & & \\
\hline \multicolumn{6}{|c|}{$\begin{array}{l}K M O=0.775 \text { Barlett's Test of Sphericity }=339.500 \text { Sig }=<0.001 \text { Overall Mean }=3.78 \\
\text { Cronbach's alpha }=0.734 F=41.454\end{array}$} \\
\hline \multicolumn{6}{|c|}{ Factor analysis of affecting the choice to tourism and hospitality } \\
\hline & Factor Loadings & Mean & Eigenvalue & AVE & $\mathbf{C R}$ \\
\hline Course Nature - Pull & & 3.524 & 2.647 & 29.415 & .639 \\
\hline $\begin{array}{l}\text { Tourism and Hospitality is an enjoyable } \\
\text { major. }\end{array}$ & .811 & 4.1225 & & & \\
\hline $\begin{array}{l}\text { Tourism and Hospitality has pleasant } \\
\text { working environment. }\end{array}$ & t.804 & 4.1618 & & & \\
\hline $\begin{array}{l}\text { There are a lot of job opportunities in this } \\
\text { field. }\end{array}$ & .527 & 4.2794 & & & \\
\hline External Impacts - Push & & 2.5997 & 1.619 & 17.993 & .653 \\
\hline My friends influenced my decision. & .816 & & & & \\
\hline $\begin{array}{l}\text { My family encouraged me to study this } \\
\text { field. }\end{array}$ & .754 & & & & \\
\hline $\begin{array}{l}\text { I did not have any specific interest but } \\
\text { because it was financially supported I } \\
\text { decided to do it. }\end{array}$ & $\begin{array}{ll}\mathrm{t} & .679 \\
\mathrm{I} & \end{array}$ & & & & \\
\hline $\begin{array}{l}\text { Pre-Course Expectations - Push and } \\
\text { Pull }\end{array}$ & & 3.8499 & 1.078 & 11.980 & .546 \\
\hline $\begin{array}{l}\text { I thought classes are more practical rather } \\
\text { than theoretical. }\end{array}$ & r . .760 & 3.5882 & & & \\
\hline $\begin{array}{l}\text { Traveling is my hobby and I wanted it as a } \\
\text { career. }\end{array}$ & a .732 & 4.1716 & & & \\
\hline $\begin{array}{l}\text { It is an easy major in comparison to other } \\
\text { fields such as business. }\end{array}$ & r .560 & 3.7598 & & & \\
\hline
\end{tabular}

\section{Correlation and Regression Analysis}

Table 3 highlights the correlation between the factors of selecting the UK choice and studying tourism and hospitality. The values indicate that there a positive correlation between the factors. The significant values are less than 0.01 . Because of this, we can conclude that there is a statistically significant correlation between choice the course and choice UK. The results in Table 3 also indicate that Opportunities and Reputation of UK Education has a significant positive relationship with Course Nature $(r=0.296 p<0.001)$, External Impacts $(r=0.248 p<0.001)$ and Pre-Course Expectations $(r=0.302$ $\mathrm{p}<0.001)$. UK Opportunities has a significant positive relationship with Course Nature $(r=0.261$ 
$\mathrm{p}<0.001)$, External Impacts $(\mathrm{r}=.234 \mathrm{p}<.001)$ and Pre-Course Expectations $(\mathrm{r}=0.462 \mathrm{p}<0.001)$. Benefits of Being an EU Member Citizens has a significant positive relationship with Course Nature ( $r=0.211$ $\mathrm{p}<0.001)$, External Impacts $(r=.384 \mathrm{p}<.001)$ and Pre-Course Expectations $(r=0.195 \mathrm{p}<0.001)$.

Table 3: Correlation analysis

\begin{tabular}{|c|c|c|c|c|c|c|c|c|}
\hline & Mean & SD & 1 & 2 & 3 & 4 & 5 & 6 \\
\hline $\begin{array}{l}\text { 1. Opportunities and Reputatic } \\
\text { of UK Education }\end{array}$ & $n 4.15$ & 0.73 & $(0.601)$ & & & & & \\
\hline 2.UK Opportunities & 3.74 & 0.76 & $.416^{* *}$ & $(0.586)$ & & & & \\
\hline $\begin{array}{l}\text { 3.Benefits of Being an EU } \\
\text { Member }\end{array}$ & 3.56 & 0.75 & $.381^{* *}$ & $.339^{* *}$ & $(0.611)$ & & & \\
\hline 4.Course Nature & 3.52 & 0.59 & $.296^{* *}$ & $.261^{* *}$ & $.211^{* *}$ & $(0.639)$ & & \\
\hline 5.External Impacts & 2.60 & 0.87 & $.248^{* *}$ & $.234^{* *}$ & $.384^{* *}$ & $.158^{* * *}$ & $0.653)$ & \\
\hline 6.Pre-Course Expectations & 3.84 & 0.67 & $.302^{* *}$ & $.462^{* *}$ & $.195^{* *}$ & $.355^{* * *}$ & $.264^{* *}$ & $(0.546)$ \\
\hline
\end{tabular}

The relationships between the factors and overall preference of students were tested by conducting a multiple regressions analysis (Table 4$)$. The result suggests that Course Nature $(\beta=0.192$ $p<.003)$, External Impacts $(\beta=0.274 p<0.001)$ and Pre-Course Expectations $(\beta=0.279 p<0.001)$ had a significant correlation with the overall preference of the students. The equation can be written (while constant was 1.653) as:

\section{Y $($ Overall Preference $)=1.653+0.279($ Pre-Course Expectations $)+0.274($ External Impacts $)+$ 0.192 (Course Nature)}

Table 4 shows the model summary result of the analysis. The independent variables (Course Nature, External Impacts, and Pre-Course Expectations) can explain 27.4\% of the variation independent variable (overall preference to select the UK for education).

Table 4. Multiple Regression Analysis

\begin{tabular}{|c|c|c|c|}
\hline \multirow[b]{2}{*}{ Factor } & \multicolumn{3}{|c|}{ Standardized Coefficients } \\
\hline & Beta & $\mathrm{t}$ & Sig. \\
\hline Course Nature & .192 & 2.992 & .003 \\
\hline External Impacts & .274 & 4.399 & .000 \\
\hline Pre-Course Expectations & .279 & 4.247 & .000 \\
\hline \multicolumn{4}{|c|}{$R=.533 R^{2}=.284 \Delta R^{2}=.274 F=26.481 \mathrm{Sig}=0.001$} \\
\hline
\end{tabular}

Note: $* p<0,01$, overall why prefer to UK for education is the dependent variable.

Table 5 displays the mean for 19 variables of research based on their importance. Among all push-pull variables for selecting the UK, the language opportunity, with a mean of 4.42 , is perceived as the most important factor. The variable with the lowest mean was "It is close to home", with a mean of 3.06". Among all push-pull variables for selecting tourism and courses, "the availability of job opportunities in this field", with a mean of 4.27, was perceived as the most important factor. 
Table 5. Mean Values of statements measuring selecting UK and selecting tourism and hospitality courses

\begin{tabular}{|c|c|c|}
\hline Factors and Variables & Mean & SD \\
\hline Selecting UK - Opportunities and Reputation of UK Education & 4.1489 & 0.726 \\
\hline I can improve my English. & $\underline{4.4216}$ & .84149 \\
\hline UK education has a global reputation. & 4.2353 & .87298 \\
\hline I can settle in the UK after study. & 3.7892 & 1.1868 \\
\hline Selecting UK - Opportunities & 3.7353 & 0.7643 \\
\hline UK is a multicultural country. & $\underline{4.2255}$ & .90871 \\
\hline UK has a good currency exchange. & 3.6716 & 1.0291 \\
\hline $\begin{array}{l}\text { It can be like a platform and I can move to a better country in the } \\
\text { future. }\end{array}$ & 3.3088 & 1.1692 \\
\hline Selecting UK - Benefits of Being an EU Member & 3.5637 & 0.7501 \\
\hline I can get financial support in the UK. & $\underline{3.8431}$ & 1.0574 \\
\hline There is not any visa issue. & 3.5294 & 1.2649 \\
\hline It is easy to find a job in the UK. & 3.7108 & 1.0361 \\
\hline It is close to home. & 3.0637 & 1.1873 \\
\hline Study Tourism and Hospitality - Course Nature & 3.524 & 0.5928 \\
\hline There are a lot of job opportunities in this field. & $\underline{4.2794}$ & .79119 \\
\hline Tourism and hospitality has pleasant working environment. & 4.1618 & .72825 \\
\hline Tourism and hospitality is an enjoyable major. & 4.1225 & .81831 \\
\hline Study Tourism and Hospitality - External Impacts & 2.5997 & 0.8687 \\
\hline My family encouraged me to study this field. & 2.8137 & 1.0984 \\
\hline My friends influenced my decision. & 2.6618 & 1.1222 \\
\hline $\begin{array}{l}\text { I did not have any specific interest but because it was financially } \\
\text { supported I decided to do it. }\end{array}$ & 2.3235 & 1.1758 \\
\hline Study Tourism and Hospitality - Pre-Course Expectations & 3.8499 & 0.6719 \\
\hline Traveling is my hobby and I wanted it as a career. & $\underline{4.1716}$ & .91241 \\
\hline & 3.7598 & .89120 \\
\hline I thought cla & 3.5882 & .98113 \\
\hline
\end{tabular}

Notes: Five-point Likert scale was used to measure perception of why abroad country, why UK and why $t / h$ education where 1 strongly disagree and 5 strongly agreed. Overall mean of 9 statement measuring why UK 3.54, overall mean of 10 measuring why t/h education 3.78.

\section{Conclusion and implications}

Using the push-pull model, this current study has tried to investigate the relative importance of the UK as a location focus for East European students to undertake HND study in tourism and hospitality at two stages: 1) selecting the UK as an educational Hub, and, 2) selecting the HND tourism and Hospitality course. The paper found a considerable range of motivating push-pull factors that shape East European students' decisions and provides a valuable insight for different stakeholders. The results reviled that the opportunities and reputation of the UK education and the benefits of being an EU member are the most important pull factors for selecting the UK as a destination. Among these, the opportunity to improve their English language, enjoying the multicultural environment and the financial support from the UK government are the most influential factors. Results for selecting tourism and hospitality courses revealed that the nature of the course, such as availability of jobs after graduation, pre course expectations and external impacts such as influence from friends and family, are the most influential factors.

The findings of the study have implications at four different levels 1) institutional level; 2) marketing and recruitment level; 3) policy makers, and 4) UK tourism and hospitality industry. At the 
classroom and institutional level, motivational factors such as the course nature and pre-course expectations (practical side) need to be considered by educational providers to adapt their teaching style, support the students' learning process, and provide them with the opportunity to build the necessary employability skills and to enhance their learning. Considering that working in the field of tourism and hospitality and an interest in traveling is mentioned by most of the students as the dominant reasons for selecting tourism and hospitality courses, adding transferable skills to the curriculum and having field trips can enhance the student experience. These initiatives are currently missing in the HND's offered by BTEC Edexcel, and the majority of the modules run are based on theory with a clear lack of practical experience. This needs to be considered by the FE providers and lecturers.

Our findings also show that financial support from the UK government is one of the main motivations among the sample group. This can answer the basic question as to how and why some students engage with the learning and thrive, while other students seem to struggle to develop their knowledge and cognitive skills. Generally, high levels of engagement are considered indicative of high levels of motivation (Hufton, Elliott, \& Illushin, 2002). This lack of interest not only influences the level of learning in the classroom, but also causes the use of ghost writers and contract cheating among the students. In the UK, commissioning of assignments, or contract cheating, has been identified as a growing problem by the HEA (Carroll, 2008) and more recently, the Quality Assurance Agency for Higher Education (QAA). The high rate of contract cheating among the students in the UK suggest that $8-9 \%$ of degrees awarded are unsafe. This needs to be considered by the FE providers and Higher Education Funding Council for England (HEFCE).

One of the most important principles of marketing is that all marketing activities should be around what the end user wants and needs (Binsardi \& Ekwuugo, 2003; Rahimi \& Kozak, 2016; Rahimi \& Gunlu, 2016; Rahimi, 2017a, Rahimi, 2017b). For education providers to succeed, they need to develop relationships between the end users and the institution. The regression model of the study show cases the main factors that influence the decision-making process of the students, and this has obvious implications for marketing departments when recruiting students from the EU and also recruitment policy makers.

At the policy-making level, the results of the study confirmed the concerns of the government regarding students' financial support and taxpayers' money. EU students are eligible for funding and according to the Student Loans Company; EU student debt has quadrupled from $£ 42$ million in 2008 to $£ 167$ million in 2011. Support from the loan company is only available to EU citizens resident in the UK for a minimum of three years. Those already living in the UK are also entitled to a maximum $£ 3,400$ maintenance loan for living costs. From 2012/13 The Student Loans Company lent almost $£ 4.5$ billion in tuition fee loans (HESA, 2013). Findings of the study shown that getting financial support from the government and freedom of work in the UK are among the "important factors" for starting the HND courses. The fact that the courses are not as time demanding as degrees gives the opportunity for students to work in the black economy.

According to the Higher Education Policy Unit, it is likely that many EU students will never pay back their UK loans. Not only is it near-impossible to enforce British tax laws in a foreign jurisdiction, but many EU countries are far poorer than the UK and salaries are lower, meaning that many graduates will never hit the $£ 21,000$ a year threshold at which repayment of the loans kicks in (The Telegraph, 2011). The findings of the study also confirmed the concern of experts that East Europen students work for "cash in hand", at the expense of the taxpayer while studying for these 
courses. Officials also admit that having less stringent entrance criteria encourages this pratice. After 2013 the government announced a freeze on new grants and revealed that all applicants from the EU had been asked for extra evidence that they were eligible for the cash, but nearly three-quarters did not respond (Mail Online, 2013). The study also addresses some of the concerns on BREXIT and the UK's discussions on leaving or remaining in the EU.

The Tourism and hospitality industry has always found it hard to attract suitably motivated, trained and qualified employees that are able to deliver the service promises that organisations make to their current and potential customers (Baum, 2008). The results of this paper present the main motivations of the generation who are currently completing, or have just completed, their further education qualifications in tourism and hospitality. Considering the lack of interest among the students and impact of external factors on their decisions to study this subject, it is difficult to say that the success and growth of tourism and hospitality industry continues. Hence tourism and hospitality industry as a whole is required to consider how newly graduated students are trained and if their qualifications have the real value for the industry.

There were some limitations in the present study. The researchers used only Tourism and Hospitality students as the sample, therefore, the findings cannot be generalised to other disciplines. Further studies could be conducted with different disciplines and the results could be compared. The data was collected from a FE provider in England and the results cannot be generalised to Scotland and Wales, other countries or HE providers. Further studies could be conducted in different regions and a comparison of the results may create an interesting picture. The findings are based on the East European students and the results might be different for Central and West Europe or internatinal students. Further studies could be done in terms of the differences based on the gender and age.

\section{References}

Altbach, P. G. (1970). The international student movement. Journal of Contemporary History, 5(1), 156-174.

Altbach, P. G. (1998). Comparative higher education: Knowledge, the university, and development. Westport: Greenwood Publishing Group.

Altbach, P. G., \& Knight, J. (2006). Visión panorámica de la internacionalización en la educación superior: Motivaciones y realidades. Perfiles educativos, 28(112), 13-39.

Baldwin, G., \& James, R. (2000). The market in Australian higher education and the concept of student as informed consumer. Journal of Higher Education Policy and Management, 22(2), 139-148. doi:10.1080/713678146

Baum, T. (2008). Implications of hospitality and tourism labour markets for talent management strategies. International Journal of Contemporary Hospitality Management, 20(7), 720-729.

Binsardi, A., \& Ekwulugo, F. (2003). International marketing of British education: research on the students' perception and the UK market penetration. Marketing Intelligence \& Planning, 21(5), 318327. doi:10.1108/02634500310490265.

Blanchflower, D. G., \& Shadforth, C. (2009). Fear, unemployment and migration. The Economic Journal, 119 (535), F136-F182. doi:10.1111/j.1468-0297.2008.02224.x. 
Bodycott, P. (2009). Choosing a higher education study abroad destination what mainland Chinese parents and students rate as important. Journal of Research in International Education, 8(3), 349-373. doi:10.1177/1475240909345818.

Bushell, R., Prosser, G. M., Faulkner, H. W., \& Jafari, J. (2001). Tourism research in Australia. Journal of Travel Research, 39(3), 323-326. doi:10.1177/004728750103900314

Carroll, J. (2008). Assessment issues for international students and for teachers of international students. The Higher Education Academy. Retrieved from http://www. hear. ac.

uk/assets/documents/rc_import/carroll.pdf.

Chow, M. Y. K., Quine, S., \& Li, M. (2010). The benefits of using a mixed methods approachquantitative with qualitative-to identify client satisfaction and unmet needs in an HIV healthcare centre. AIDS Care, 22(4), 491-498. doi:10.1080/09540120903214371.

Cole, J. S., Cole, S. T., \& Ferguson, A. P. (2006). Students' motivation to learn: A comparison between undergraduate students majoring in parks, recreation, and tourism and those in other majors. Journal of teaching in travel \& tourism, 6(2), 61-70. doi:10.1300/J172v06n02_05.

Dale, C., \& Robinson, N. (2001). The theming of tourism education: A three-domain approach. International Journal of Contemporary Hospitality Management, 13(1), 30-35. doi:10.1108/09596110110365616.

Davey, G. (2005). Chinese students' motivations for studying abroad. International Journal of Private Education, 2, 16-21.

Dörnyei, Z. (1998). Motivation in second and foreign language learning. Language Teaching, 31(3), 117-135. doi:10.1017/S026144480001315X.

Elo, S., \& Kyngäs, H. (2008). The qualitative content analysis process. Journal of Advanced Nursing, 62(1), 107-115.

Faulkner, B. (2003). Progressing tourism research. Clevedon: Channel View Publication.

Gomes, L., \& Murphy, J. (2003). An exploratory study of marketing international education online. International Journal of Educational Management, 17(3), 116-125.

Greene, J. C., Caracelli, V. J., \& Graham, W. F. (1989). Toward a conceptual framework for mixedmethod evaluation designs. Educational Evaluation and Policy Analysis, 11(3), 255-274. doi:10.3102/01623737011003255.

Hair Jr, J. F., \& Lukas, B. (2014). Marketing research. Australia: McGraw-Hill.

Hair, J. F., Celsi, M. W., Money, A. H., Samouel, P., \& Page, M. J. (2015). Essentials of business research methods. New York: ME Sharpe.

Hannam, K., Mitsche, N., Stone, C., \& Mordue, T. (2004). Tourism employability and the European social fund. In Critical Issues in Tourism Education: Conference of the Association for Tourism in Higher Education (pp. 39-52). Missenden Abbet Buckinghamshire, UK.

HESA. (2013). HE Statistics for the UK 2012/13. Retrieved from https://www.hesa.ac.uk/pr208 . 
HESA. (2015). Higher education student enrolments and qualifications obtained at higher education providers in the United Kingdom 2014/15. Retrieved from https://www.hesa.ac.uk/pr/3771-statisticalfirst-release-224.

Hsieh, H. F., \& Shannon, S. E. (2005). Three approaches to qualitative content analysis. Qualitative Health Research, 15(9), 1277-1288.

Hufton, N. R., Elliott, J. G., \& Illushin, L. (2002). Educational motivation and engagement: Qualitative accounts from three countries. British Educational Research Journal, 28(2), 265-289.

Huyton, J. R. (1997). The implications of cross-cultural communication in the hotel industry: A Chinese case. In CAUTHE 1997: Tourism research: Building a better industry; Proceedings from the Australian Tourism and Hospitality Research Conference, 1997 (p. 158). Bureau of Tourism Research.

Independent/Madalina Ciobanu (2013). Why is the UK biased against students from Romania and Bulgaria?. Retrieved from http://www.independent.co.uk/student/why-is-the-uk-biased-againststudents-from-romania-and-bulgaria-8435644.html.

James, R., McInnis, C., \& Devlin, M. (2002). Assessing learning in Australian Universities: Ideas, strategies and resources for quality in student assessment. Australian Universities Teaching Committee.

Kim, S. S., Guo, Y., Wang, K. C., \& Agrusa, J. (2007). The study motivations and study preferences of student groups from Asian nations majoring in hospitality and tourism management programs. Tourism Management, 28(1), 140-151. doi:10.1016/j.tourman.2005.11.003.

King, R., \& Ruiz- Gelices, E. (2003). International student migration and the European 'year abroad': effects on European identity and subsequent migration behaviour. International Journal of Population Geography, 9(3), 229-252. doi:10.1002/ijpg.280.

Kozak, M., \& Kozak, N. (2017). Institutionalisation of tourism research and education: from the early 1900s to 2000s. Journal of Tourism History, 1-25.

Kyriacou, C., \& Coulthard, M. (2000). Undergraduates' views of teaching as a career choice. Journal of Education for Teaching: International Research and Pedagogy,26(2), 117-126. doi:10.1080/02607470050127036.

Lee, M. J., Kim, S. S., \& Lo, A. (2008). Perceptions of hospitality and tourism students towards study motivations and preferences: A study of Hong Kong students. Journal of Hospitality, Leisure, Sports and Tourism Education (Pre-2012), 7(2), 45. doi:10.3794/johlste.72.178.

Li, M., \& Bray, M. (2007). Cross-border flows of students for higher education: Push-pull factors and motivations of mainland Chinese students in Hong Kong and Macau. Higher Education, 53(6), 791818. doi:10.1007/s10734-005-5423-3.

Mail Online (2013). one in six college applicants is Romanian or Bulgarian: More than 5,000 apply for vocational courses with many entitled to up to £10,000 in grants and loans. Retrieved from http://www.dailymail.co.uk/news/article-2510092/One-college-applicants-Romanian-

Bulgarian.html. 
Maringe, F., \& Carter, S. (2007). International students' motivations for studying in UK HE: Insights into the choice and decision making of African students. International Journal of Educational Management, 21(6), 459-475.

Mazzarol, T., \& Soutar, G. N. (2001). The global market for higher education: Sustainable competitive strategies for the new millennium. Northammpton: Edward Elgar Publishing.

Mazzarol, T., \& Soutar, G. N. (2002). "Push-pull" factors influencing international student destination choice. International Journal of Educational Management, 16(2), 82-90.

McMahon, M.E. (1992), Higher education in a world market: An historical look at the global context of international study. Higher Education, 24(4), 465-82. doi:10.1007/BF00137243.

Moogan, Y. J., \& Baron, S. (2003). An analysis of student characteristics within the student decision making process. Journal of Further and Higher Education, 27(3), 271-287. doi:10.1080/0309877032000098699.

Moogan, Y. J., Baron, S., \& Harris, K. (1999). Decision- making behaviour of potential higher education students. Higher Education Quarterly, 53(3), 211-228. doi:10.1111/1468-2273.00127.

O'Brien, A., Webb, P., Page, S., \& Proctor, T. (2007). A study into the factors influencing the choicemaking process of Indian students when selecting an international university for graduate studies using grounded theory. Paper presented at the conference in Amsterdam in the Netherlands, July 2007. Retrieved from http://hdl.handle.net/10034/37772 .

O'Mahony, B., Whitelaw, P. A., \& McWilliams, A. (2008). The drivers of program selection in hospitality management at Victoria University. Journal of Hospitality \& Tourism Education, 20(3), 510. doi:10.1080/10963758.2008.10696915.

O'Mahony, G. B., McWilliams, A. M., \& Whitelaw, P. A. (2001). Why students choose a hospitalitydegree program an Australian case study. The Cornell Hotel and Restaurant Administration Quarterly, 42(1), 92-96. doi:10.1177/0010880401421011.

Pallant, J. (2007). SPSS survival manual: A step-by-step guide to data analysis using SPSS version 15. Buckingham: Open University Press.

Pintrich, P. R. (2003). A motivational science perspective on the role of student motivation in learning and teaching contexts. Journal of Educational Psychology, 95(4), 667-686. doi:10.1037/00220663.95.4.667.

Pintricht, P. L., \& Schunk, D. H. (2002). Motivation in education: Theory, research and applications. NJ: Prentice Hall.

Pishghadam, R., \& Khajavy, G. H. (2014). Development and validation of the student stroke scale and examining its relation with academic motivation. Studies in Educational Evaluation, 43, 109-114. doi:10.1016/j.stueduc.2014.03.004.

Purcell, K., \& Quinn, J. (1996). Exploring the education-employment equation in hospitality management: A comparison of graduates and HNDs. International Journal of Hospitality Management, 15(1), 51-68. doi:10.1016/0278-4319(96)00002-3. 
Rahimi, R. (2017a). Organizational Culture and Customer Relationship Management: A Simple Linear Regression Analysis. Journal of Hospitality Marketing \& Management. DOI: 10.1080/19368623.2017.1254579.

Rahimi, R. (2017b) Customer Relationship Management (People, Process and Technology) and Organisational Culture in Hotels: Which traits matter?. International Journal of Contemporary Hospitality Management. 29 (5) . DOI: 10.1108/IJCHM-10-2015-0617.

Rahimi, R., \& Gunlu, E. (2016). Implementing customer relationship management (CRM) in hotel industry from organizational culture perspective: Case of a chain hotel in the UK. International Journal of Contemporary Hospitality Management, 28(1), 89-112. doi:10.1108/IJCHM-04-20140176.

Rahimi, R., \& Kozak, M. (2016). Impact of customer relationship management on customer satisfaction: The case of a budget hotel chain. Journal of Travel \& Tourism Marketing, 34(1), 40-51. doi:10.1080/10548408.2015.1130108.

Rahimi, R., Nadda, V., \& Muldiwa, D. (2016). Motivations of Asian students to study tourism and hospitality in the UK: Case of Indian, Bangladeshi, Pakistani and Nepali Students. In, Kozak, M and Kozak, N: Tourism and Hospitality Management: Emerald Book Series.

Rahimi, R., Williams, S., Gursoy, D., Yolal, M., \& Lee, T. (2015). Motivations of eastern European students to study tourism and hospitality (HND level) in the UK: Case of Romanian students. In The 5th Advances in Hospitality \& Tourism Marketing and Management (AHTMM) Conference, Beppu, Japan, 18-21 June 2015. (pp. 359-365). Washington State University.

Ritchie, J., Spencer, L., Bryman, A., \& Burgess, R. G. (1994). Analysing qualitative data. London: Routledge.

Ross, G. F. (1992). Tourism management as a career path: Vocational perceptions of Australian school leavers. Tourism management, 13(2), 242-247.

Ruhanen, L., \& McLennan, C. L. J. M. (2010). 'Location, Location, location'-the relative importance of country, institution and program: A study of tourism postgraduate students. Journal of Hospitality and Tourism Management, 17(1), 44-52. doi:10.1375/jhtm.17.1.44.

Stuart-Hoyle, M. (2003). The purpose of undergraduate tourism programmes in the United Kingdom. Journal of Hospitality, Leisure, Sport and Tourism Education,2(1), 49-74. doi:10.3794/johlste.21.28

Suvantola, J. (2004). Self-determination theory in charting students' motivation. In J. Tribe \& E. Wickens (Eds.), Critical issues in tourism education: Proceedings of the 2004 Conference of the Association for Tourism in Higher Education (pp. 139-144).

The Telegraph. (2011). EU students get a better deal at British universities. Retrieved from http://www.telegraph.co.uk/education/universityeducation/8553427/EU-students-get-a-better-deal-atBritish-universities.html.

The Telegraph/ Graeme Paton,. (2010). Rise in European students at UK universities. Retrieved from http://www.telegraph.co.uk/education/educationnews/7521294/Rise-in-European-students-atUK-universities.html. 
UCAS. (2016). Higher education in the UK. Retrieved from https://www.ucas.com/ucas/undergraduate/getting-started/international-and-eu-students/ucasterms-explained.

UKCISA. 2016. International student statistics: UK higher education. Retrieved from http://institutions.ukcisa.org.uk//info-for-universities-colleges--schools/policy-research-statistics/research--statistics/international-students-in-uk-he/.

Varghese, N. V. (2008). Globalization of higher education and cross-border student mobility. Paris: Unesco, International Institute for Educational Planning.

Ward, C., \& Masgoret, A. M. (2004). The experiences of international students in New Zealand. Report on the Results of a National Survey. Wellington: Ministry of Education.

Weinberger, J., \& McClelland, D.C. (1990). Cognitive versus traditional motivational models? Irreconcilable or complementary? In E.T. Higgins \& R.M. Sorrentino (Eds.), Hand-book of motivation and cognition (Vol. 2, pp. 562-597). New York, NY: Guilford.

Wickens, E., Forbes, A., \& Tribe, J. (2006). Listening, understanding and responding to leisure and tourism undergraduates. Journal of Hospitality, Leisure, Sport and Tourism Education, 5(2), 4-13. doi:10.3794/johlste.52.100.

Williams, M., Burden, R., \& Lanvers, U. (2002). 'French is the language of love and stuff': Student perceptions of issues related to motivation in learning a foreign language. British Educational Research Journal, 28(4), 503-528. doi:10.1080/0141192022000005805.

Zhao, J. L. (1991). A current look at hospitality and tourism education in China's colleges and universities. International Journal of Hospitality Management, 10(4), 357-367. doi:10.1016/02784319(91)90017-C. 